\title{
SENI LUKIS SOKARAJA: PROSES PEWARISAN DAN PEMASARANNYA DALAM KONTEKS PASAR SENI
}

\author{
Fery Setyaningrum \\ Prodi Pendidikan Seni, Program Pascasarjana, Universitas Negeri Semarang \\ E-mail: feSetya@gmail.com
}

\begin{abstract}
Abstrak
Seni lukis Sokaraja pernah menjadi perhatian publik, dalam kurun waktu yang realitif lama, yakni tahun 1960-1980an. Pada perkembangannya lukisan Sokaraja dimasyarakat pada saat ini masih tetap ada, sekalipun tidak semaju di masa jayanya. Tampaknya ada proses pewarisan yang berlanjut, pewarisan terjadi pada proses belajar nonformal dan informal. Terbukti sampai saat ini masih muncul lukisan baru yang ada di pasaran.Tujuan penelitian ini adalah mendeskripsikan dan menganalisis karakteristik seni lukis Sokaraja, proses pewarisan dan pemasarannya dalam konteks pasar seni. Pendekatan penelitian ini adalah interdisiplin, dengan metode kualitatif. Hasil penelitian menunjukkan. Pertama, ditemukan karakteristik seni lukis Sokaraja berdasarkan unsur rupa yang hampir sama, pada lukisan dulu (raut lebih banyak dan warna lebih sedikit), sedangkan pada lukisan saat ini (raut lebih sedikit dan warna lebih banyak). Komposisi kedua lukisan hampir sama, berbeda pada irama dan dominasi, perbedaan tema lukisan dulu (alam fisik sokaraja) dengan sekarang (beranekaragam), kedua lukisan berupa aliran naturalisme. Kedua, pada pewarisan adanya empat yang mencapai enkulturasi. Berupa proses belajar melukis di sanggar dan keluarga. Ketiga, pada pemasaran adanya managemen marketing pada pelukis dan galeri. Fakta perencanaan, promosi dan pendistribusianyang ada pada pelukis dan galeri berdampak pada kondisi perkembangan pasar seni lukis Sokaraja yang makin menurun.
\end{abstract}

Kata Kunci : Seni Lukis Sokaraja, Pewarisan, Proses Belajar, Pemasaran

\section{SOKARAJA PAINTING ARTS: THE PROCESS OF ITS INHERITANCE AND MARKETING IN THE CONTEXT OF ART MARKET}

\begin{abstract}
Sokarajas painting had become public attention in a relatively long period between 1960s and 1980s. In its developmental stage, Sokaraja paintings nowadays still persist in the comunity although they are not as good as they were in their prime time. There seems to be an inheritance process continuing, in the level of nonformal and informal learning. This process is proven by the fact that until now the paintings still appear on the market. The purpose of this research is to describe and analyze the characteristics of Sokaraja paintings, the process of inheritance and marketing in the context of art market. This study uses an interdisciplinary approach, with the qualitative methods. The research results indicate that first, the characteristics of Sokaraja paintings are found, having almost the same elements of painting as the previous painting (more shapes and fewer colors). The composition of both are almost the same. The difference lies on its rhymes and domination, the earlier themes
\end{abstract}


(physical nature of Sokaraja's rural areas) and the present ones (many kinds natural scenes). All of the paintings are naturalist. Second, on the inheritance process lies on the fact that there are four achieving inculturation, by means of learning process to paint in studio and in the family group. Third, in the marketing process, there is a kind of marketing management of the painters or gallery. The fact of planning, promotion, and distribution of paintings have impact on the decrease in Sokaraja painting market.

Keywords : sokaraja painting, Inheritance, Learning Process, Marketing

\section{PENDAHULUAN}

Seni adalah fenomena yang misterius, sekilas adalah sesuatu yang tidak pokok, tidak penting, ketika segala aktivitas kehidupan kini dikelola berdasarkan nalar-ilmiah, teknologis yang memuja perhitungan, objektivitas dan efisensi. Ironisnya, pada saat yang sama kini "seni" justru menjadi kata kunci penentu disegala bidang hidup manusia (Sugiharto, 2013: 5). Begitu pula dimasyarakat, seni menjadi hal yang sering diabaikan, padahal hidup manusia tidak akan pernah jauh dari seni. Bahkan, seni menjadi sesuatu yang sangat penting oleh beberapa kalangan masyarakat. Salah satu contohnya adalah kehidupan seni lukis di Sokaraja. Di daerah Sokaraja terdapat seni lukis aliran naturalisme yang biasa dikenal sebagai karya seni rakyat atau karya seni lukis pinggiran. Kreator atau pelukisnya rata-rata berasal dari masyarakat asli Sokaraja, hal tersebut tidak terlepas dari peran masyarakat Sokaraja sendiri sebagai pelaku, pendistribusi dan sebagai konsumen karya lukis Sokaraja.

Lukisan pemandangan gaya Sokaraja, Banyumas masuk gaya Mooi Indie atau Hindia Molek sebenarnya adalah mazhab atau cara pandang kolonialisme Belanda. lukis Sokaraja yang tetap relevan dalam konteks kebudayaan Jawa khususnya atau Indonesia pada umumnya. Adanya Adagium 'gemah ripah loh jinawi" dalam kultur Jawa memberikan pembenaran atas fenomena lseni lukis Sokaraja. Pandangan itu bukan sekadar idealisasi suatu kondisi, namun implikatif pula. Sederhananya, rakyat banyak menginginkan suatu cantolan atau pembenar atas prinsip-prinsip kehidupan yang diyakininya. Seni lukis Sokaraja adalah gambaran ideal masyarakat jawa mengenai: Indonesia yang permai.

Pada kurun waktu hampir dua dasawarsa ini, seni lukis Sokaraja seolah lenyap ditelan zaman seiring berkembangnya Sokaraja menjadi daerah perdagangan yang cukup ramai. Karena Sokaraja merupakan daerah satelit dari Purwokerto Jawa Tengah.Hal tersebut menjadikan keprihatinan, berangkat dari sebuah konsep tema yang sama dan jenis yang hampir sama dengan lukisan santir gaya mooi hindie namun sangat berbeda dari segi perkembangannya, hal tersebut menjadi tanda-tanya. Sudah pasti adanya beberapa faktor 
yang kurang mendukung, kaitannya dalam proses pewarisan atau mungkin strategi pemasarannya.

Pada ranah pewarisan dalam konteks pendidikan, tampaknya seni lukis Sokaraja masuk dalam kategori pendidikan nonformal dan informal yakni pendidikan yang dilakukan di sanggar dan di masyarakat atau keluarga yang berimplikasi pada pendidikan seni lukis di sanggar-sanggar dan di keluarga atau di masyarakat.Dilihat dari sisi pemasarannya, jelaslah seni lukis Sokaraja memiliki pangsa pasar tersendiri di pasaran seni Indonesia. Selain itu, ada kaitan antara pemasaran dengan kegiatan apresiasi, ketika lukisan dibeli akan terjadi kegiatan apresiasi dimasyarakat. Berdasarkan pemikiran itulah maka peneliti merasa tertarik untuk melihat bagaimana proses pewarisan dan proses pemasaran seni lukis Sokaraja.

\section{METODE PENELITIAN}

Penelitian ini menggunakan pendekatan interdisiplin, dalam pengertian menggunakan lebih dari satu disiplin ilmu menjadi satu dalam mengkaji sebuah permasalahan (Rohidi, 2011: 61). Disiplin ilmu yang digunakan untuk mengkaji masalah penelitian ini adalah bidang kesenirupaan, antropologi budaya, dan ekonomi. Bidang kesenirupaan untuk melihat wujud atau fisik seni lukis Sokaraja, antropologi digunakan untuk mengkaji proses pewarisan seni lukis Sokaraja, dan bidang ekonomi digunakan untuk mengkaji pemasaran seni lukis Sokaraja.

Penelitian ini menggunakan metode kualitatif. Dalam penelitian kualitatif data yang akan muncul berwujud kata-kata dan bukan rangkaian angka, dengan pengumpulan data menggunakan observasi, wawancara, studi dokumen kemudian diproses dan dianalisis. Sasaran kajian dalam penelitian ini adalah tentangseni lukis Sokaraja, yang difokuskan pada karakteristik lukisan, proses pewarisan dan pemasarannya dalam konteks pasar seni. Teknik pengumpulan data menggunakan observasi, wawancara, studi dokumen. Teknik keabsahan data secara utama menggunakan triangulasi sumber. Teknik analisis data yang digunakan adalah analisis data interaktif. Kemudian, peneliti juga menggunakan konsep etik-emik, etik yang dimaksud di sini adalah pijakan teori, sedangkan emik adalah data di lapangan yang diinterpretasikan oleh peneliti.

\section{HASIL DAN PEMBAHASAN}

Guna menjawab masalah penelitian yang berkaitan dengan permasalahan karaketristik seni lukis Sokaraja, peneliti secara pokok menggunakan disiplin ilmu seni 
rupa. Konsep kesenirupaan yang digunakan secara utama menggunakan konsep kesenirupaan dari Sunaryo (2002), Rondhi \& Sumartono (2002).

Dalam pembahasan itu, apabila hanya menggunakan konsep yang diuraikan di atas dianggap belum dapat menjawab permasalahan secara tuntas, oleh karena itu dalam jurnal penelitian ini, dalam pembahasannya juga dilengkapi dengan berbagai konsep dari literarur yang lain. Perihal hasil penelitian dan pembahasan itu. Pemaparannya, tidak akan dipisah. Hal ini dikarenakan, setiap pembahasan hasil dari penelitian ini, dijelaskan menggunakan dasar pemikiran etik dan emik, yang hasilnya hanya akan didapat dan dipahami dari gabungan berbagai unsur yang dibahas tadi.

Berdasarkan konsep kesenirupaan di atas maka ditemukan untuk gaya lukisan Sokaraja yang masih asli sebagian besar menggunakan konsep lukisan yang berlatar pemandangan alam di persawahan dan gunung, namun beberapa pelukis sudah terpengaruh gaya lukisan dari daerah lain yakni gaya lukisan seperti di daerah sunda yakni dengan berlatar pemandangan tempat di air terjun, dengan unsur estetika yang berbeda pula dengan gaya lukisan asli di Sokaraja. Sebagai usaha menyampaikan hasil penelitian dan pembahasan mengenai pembuatan lukisan Sokarja di tahun 1960-1980. Maka, diuraikan persiapan alat dan bahan dan proses pembuatan. Sokaraja terdahulu.

Sebelum para pelaku seni di Sokaraja memulai melukis, ada beberapa persiapan yang dilakukan, antara lain persiapan alat dan bahan-bahan untuk melukis. Di bawah ini akan di cantumkan beberapa foto hasil dokumentasi peneliti di rumah Bapak Abdul Basir, salah satu pelukis Sokaraja berumur 88 tahun, beliau kesehariannya hanya melukis dan sampai sekarang (2015) masih melukis sebagai mata pencaharian dan pendapatan utama, untuk lebih jelasnya akan di uraikan sebagai berikut Foto dokumentasi yang pertama ini merupakan bahan-bahan dan alat yang digunakan Bapak Abdul Basir untuk melukis.

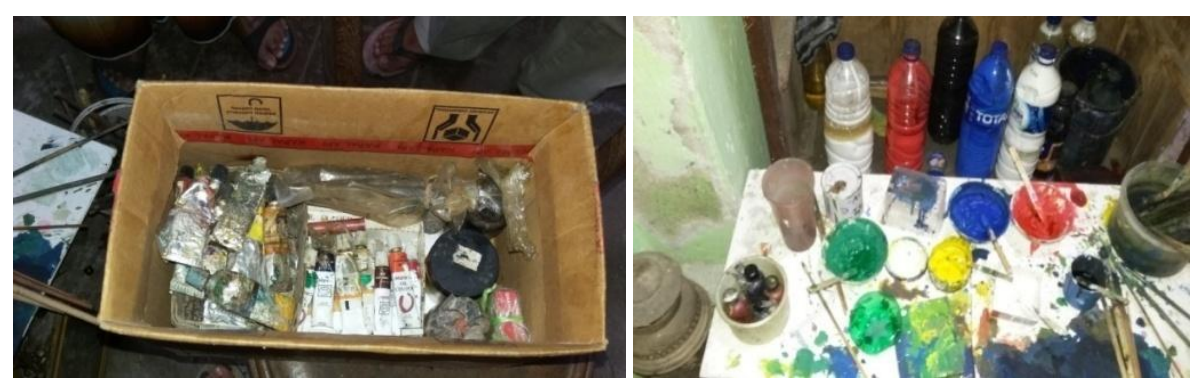

Gambar 1. Foto Bahan Cat yang Digunakan Pak

Basir dalam Melukis

(Dokumentasi Setyaningrum, 2015)

Pembuatan Lukisan Sokaraja di tahun (1990 hingga sekarang 2015), alat dan bahan yang digunakan melukis Sokaraja sudah menggunakan bahan dan alat yang sudah modern, 
dari kuas yang digunakan menggunakan kuas yang sudah jadi dengan membelinya langsung di toko. Kanvas yang dipake juga sudah menggunakan variasi kanvas yang sudah bagus. Yang dalam ketahanan catnya akan dapat beberapa kurun waktu lebih lama di banding dengan menggunakan kanvas biasa. Pada persiapan alat nya pun pelukis sudah menggunakan cungkir sebagai finishing melukis. Pada catnya pun pelukis sudah menggunakan merk cat akrilik yang sudah cukup bagus dan dapat ditemukan pada tokotoko alat bahan untuk melukis. Untuk lebih jelasnya gambar dan keterangan alat dan bahan, sebagai berikut ini :
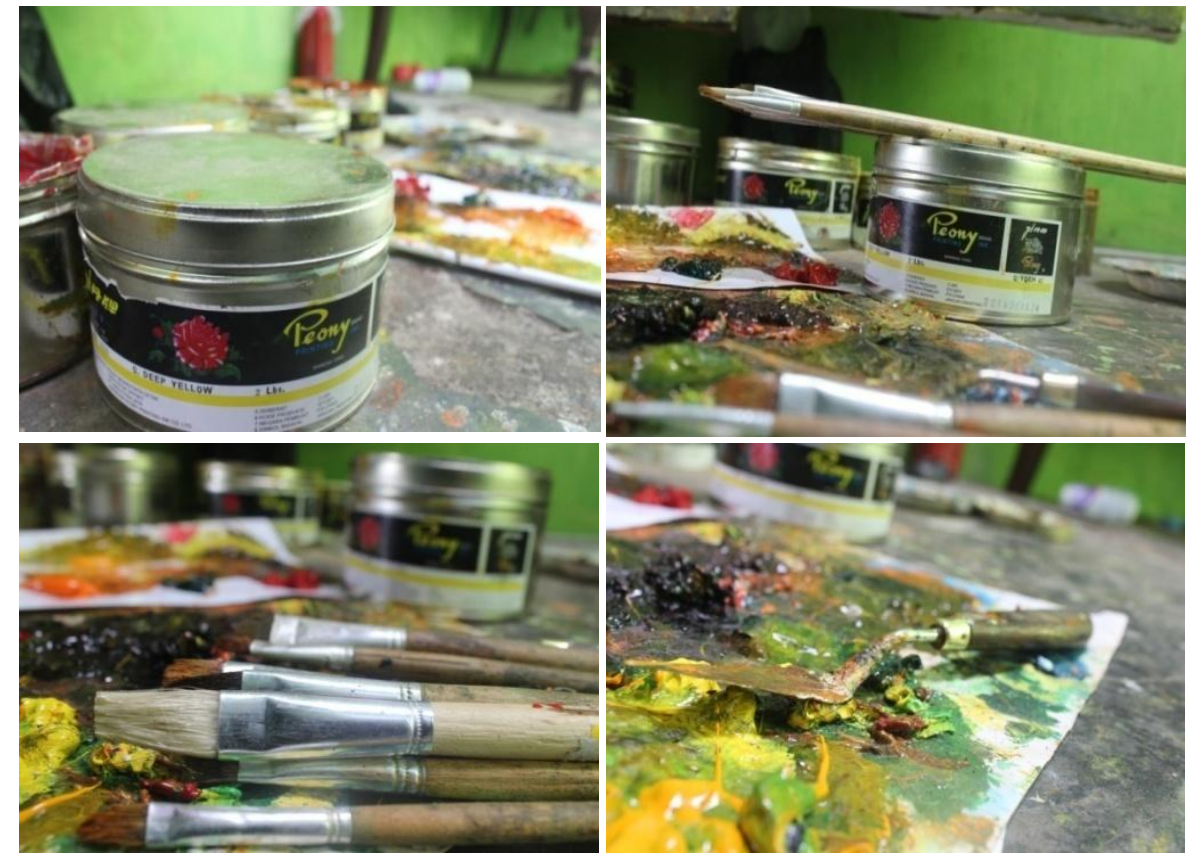

Gambar 2. Bahan dan alat Melukis Berupa Cat Peony Kuas dan Cungkir (Dokumentasi Setyaningrum, 2015)

Gambar di atas menunjukan alat untuk melukis, alat tersebut sebagai langkah akhir setelah pelukis selesei melukis pemandangan, dan difinishing dengan menempelkan cat kecil-kecil dengan meggunakan Cungkir. Hal tersebut menurut pelukis, menjadikan lukisan Sokaraja makin bagus dan indah.
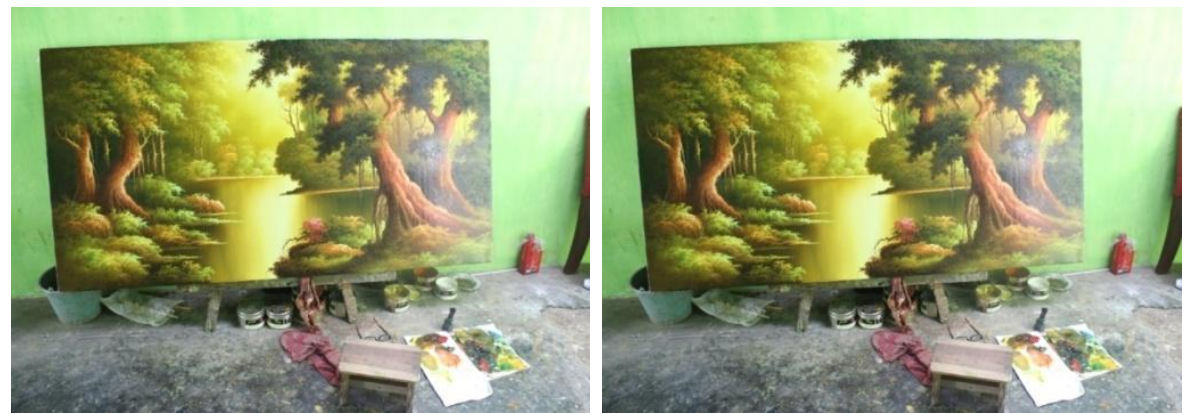

Gambar 3. Alat Pendukung Melukis Berupa Tempat Duduk Kecil Biasa Dingklik Digunakan untuk duduk Saat Melukis (Dokumentasi Setyaningrum, 2015) 
Berdasarkan keterangan gambar di atas terdapat foto alat lukis berupa alat pembantu yakni berupa dingklik (tempat duduk kecil) sebagai upaya membantu dan memudahkan pelukis berada dalam posisi nyaman ketika melukis. Alat lainnya berupa penahan lukisan yang berbahan dasar kayu berfungsi menahan lukisan dalam posisi tidak terjatuh dan membantu pelukis dalam kenyamanan ketika menorehkan cat dalam menuangkan ide pada kanvas.

Kemudian di bawah ini ditemukan data hasil observasi mengenai kegiatan Bapak Sugeng yakni salah satu pelukis di Sokaraja, beliau melakukan kegiatan melukis di rumahnya, dan dalam gambar hasil dokumentasi foto dari observasi tersebut, ada beberapa rangkaian urutan kegiatan melukis yang dilakukan Bapak Sugeng, dari membuat dasaran lukisan hingga finishing lukisan, untuk lebih jelasnya rangkaian aktifitas melukis Sokaraja adalah sebagai berikut :
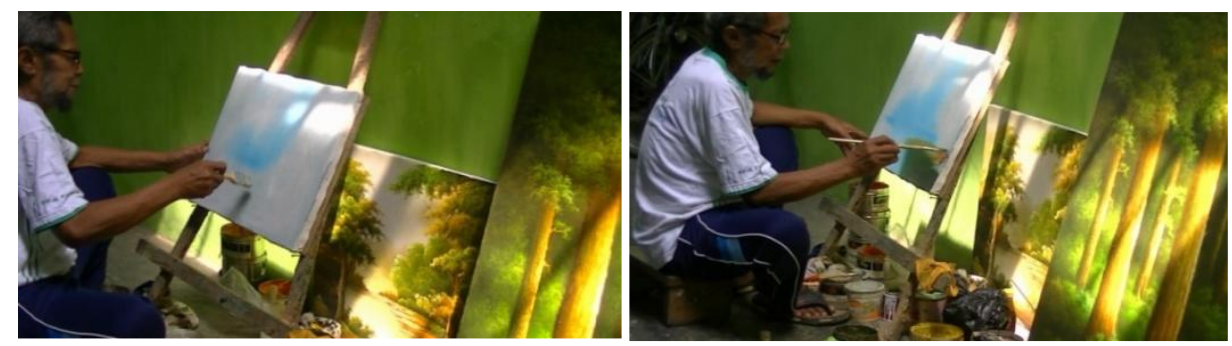

\section{Gambar 4. Aktivitas Melukis Bapak Sugeng Lokasi Di Rumah Bapak Sugeng dari Membuat Dasaran Lukisan Awal} (Dokumentasi Setyaningrum, 2015)
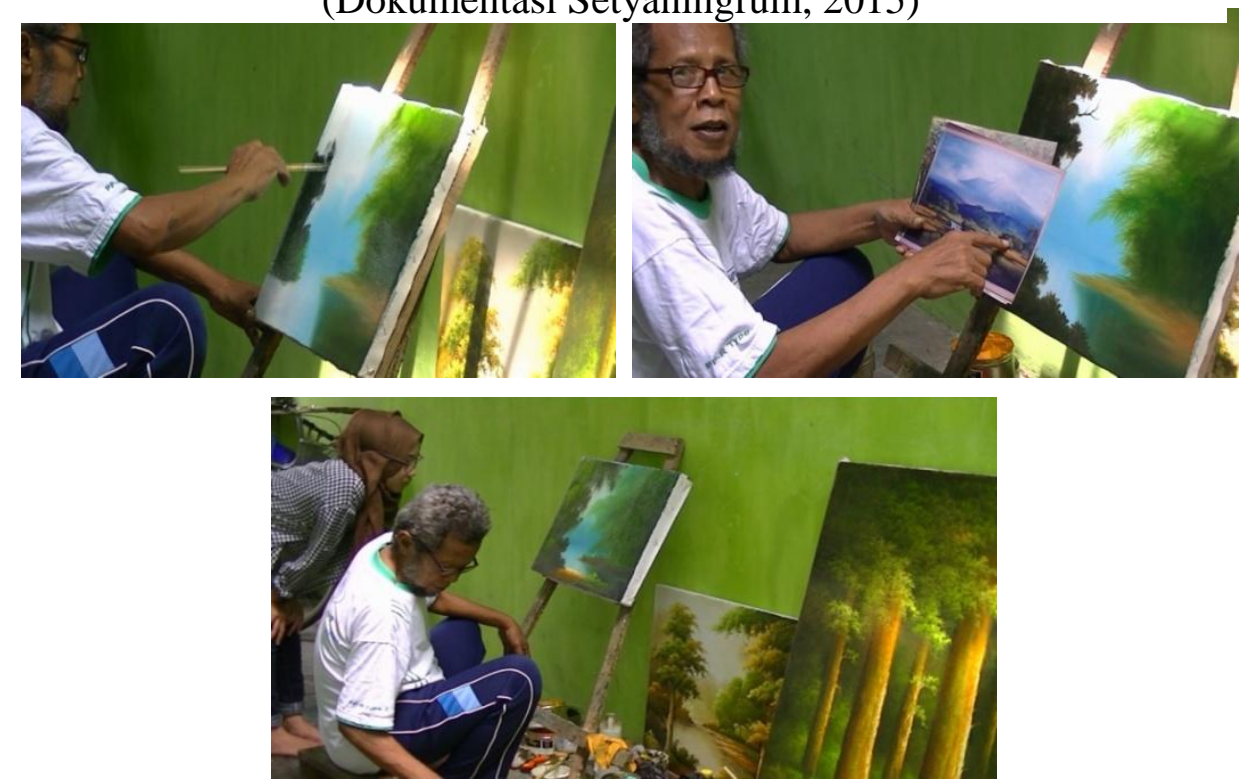

Gambar 5. Aktivitas Pak Sugeng Sedang Melukis Di Rumah Membuat Obyek Pepohonan hingga Finishing

Memperlihatkan referensi foto-foto terdahulu

(Dokumentasi Setyaningrum, 2015) 
Gambar di atas merupakan gambar aktifitas Pak Sugeng yang sudah selesai melukis dengan kanvas ukuran kecil yakni ukuran 30x40an, dalam kegiatan tersebut terlihat lukisan pemandangan yang sudah tampak jadi, Pak Sugeng mengecek kembali hasil lukisannya sembari membersihkan sisa-sisa cat bahan melukis dan membereskan alat-alat yang digunakan untuk melukis. Berdasarkan hasil lukisan-lukisan milik Bapak Sugeng warnawarna yang digunakan cenderung ke warna kuning keemasan. Finishingnya pun menggunakan alat cungkir untuk menorehkan cat setelah lukisan dilukis menggunakan kuas.

Guna mengetahui bagaimana pewarisan cara pembuatan lukisan Sokaraja maka perlunya konsep mengenai unsur-unsur rupa, yakni tentang ; garis, raut, warna, tekstur, gelap terang, ruang. Setelah ditambahkannya konsep baru tersebut guna memperkuat interpretasi peneliti pada saat menganalisis karya lukisan Sokaraja, maka di bawah ini akan ditampilkan foto hasil dokumentasi dari observasi langsung di Sokaraja, karya lukisan Sokaraja berkisar tahun 1960-1980an, untuk lebih jelasnya gambar akan dipaparkan sebagai berikut di bawah ini.

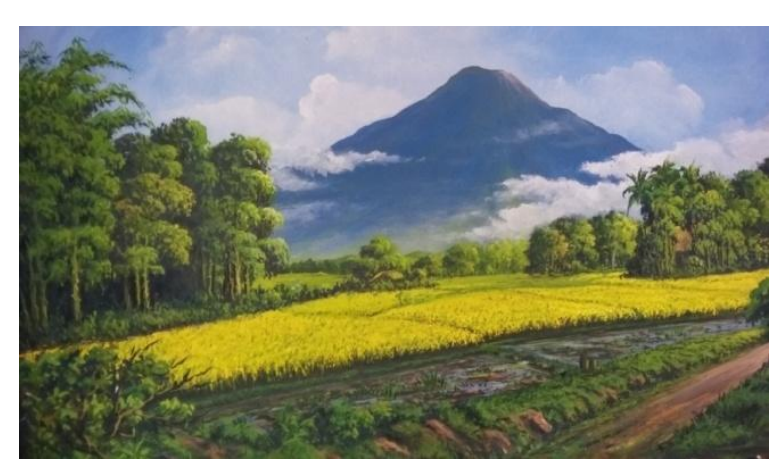

Gambar 6. Contoh

Lukisan Sokaraja terdahulu

(Dokumentasi Setyaningrum, 2015)

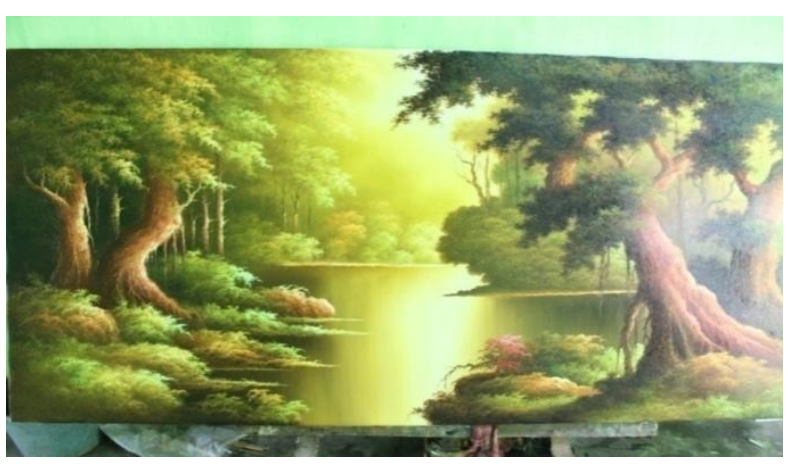

Gambar 7. Lukisan Sokaraja

Pada Saat Ini (2015)

Pelukis Bapak Sugeng

(Dokumentasi Setyaningrum, 2015)

Setelah melihat hasil observasi berupa dokumentasi karya lukisan Sokaraja diatas, kemudian dihubungkan dengan konsep unsur-unsur seni rupa yang akan diuraikan berikut ini, dari unsur yang pertama yakni tentang garis, sebelum unsur rupa garis, ada yang memandang titik atau noktah (spot) sebagai unsur yang paling sederhana (Bates dalam Sunaryo, 2002: 7). Sedangkan, garis merupakan unsur rupa (visual element) yang paling sederhana setelah titik. Garis dapat dibedakan menjadi dua macam, yaitu garis yang nyata (konkret) dan garis maya (imajinatif). Garis nyata yaitu garis sebagai wujud konkret benar- 
benar nyata atau berwujud kehadirannya, misalnya garis yang menggambarkan batas keliling suatu benda. Garis maya (imajinatif) adalah garis yang secara visual tidak ada namun keberadaannya dapat kita pahami (Rondhi dan Sumartono, 2002: 31).

Kemudian untuk unsur rupa raut adalah pengenal bentuk yang utama. Sebuah bentuk dapat dikenali dari rautnya, apakah sebagai suatu bangun yang pipih datar, yang menggumpal padat atau berongga bervolume, lonjong, bulat, persegi, dan sebagainya. Raut dapat ditampilkan dengan kontur (Sunaryo, 2002: 9). Setelah peneliti menganalisis berbagai macam raut di lukisan Sokaraja, unsur selanjutnya adalah warna. Tekstur (texture) atau barik, ialah sifat permukaan. Sifat permukaan dapat halus, polos, kasap, licin, mengkilap, berkerut, lunak, keras, dan sebagainya. Setiap material atau bahan memiliki teksturnya masing-masing. Permukaan kulit kayu, batu atau marmer, kaca, tekstil, anyaman bambu, dan lain-lain, memiliki tekstur masing-masing yang khusus (Sunaryo, 2002: 17). Barik menurut Wong (1986: 3-4) ialah kaifiat permukaan raut.

Ungkapan gelap terang sebagai hubungan pencahayaan dan bayangan dinyatakan dengan gradasi mulai dari yang paling putih untuk menyatakan sangat terang, sampai kepada yang paling hitam untuk bagian yang gelap (Sunaryo, 2002:20) . Ruang terkait dengan raut dan bentuk. Ruang pictorial adalah ruang yang bersifat maya atau ilusif karena karena dalam karya dua dimensi ruang tersebut kenyataannya tidak ada, sedangkan ruang fisik adalah ruang aktual yang letaknya berdampingan dengan bentuk-bentuk tiga dimensional (Lowry dalam Rondhi, 2002:34).

Konsep komposisi menjadi penting untuk memecahkan dan menganalisis karya hasil dokumentasi gambar di atas, komposisi dalam seni rupa terdiri dari kesatuan, keserasian, dominasi, keseimbangan, kesebandingan. Kesatuan menurut The Liang Gie (dalam Alfauzani, 2008 : 16), berarti setiap unsur dalam sebuah karya seni adalah perlu bagi terciptanya nilai karya seni dan karya tersebut tidak memuat unsur-unsur yang tidak perlu dan unsur yang hadir tersebut harus saling mendukung, memerlukan, menanggapi, dan menuntut setiap unsur yang lainnya. Kesatuan (unity) menurut Sunaryo (2002:31) merupakan prinsip pengorganisasian unsur-unsur rupa yang paling mendasar. Tujuan akhir dari penerapan prinsip-prinsip desain yang lain, seperti keseimbangan, kesebandingan, irama, dan lainnya adalah untuk mewujudkan kesatuan yang padu atau keseutuhan.

Proporsi menurut Syakir dan Mujioyono (2007: 62) adalah aspek kesebandingan yaitu hubungan ukuran antar bagian satu dengan bagian lainnya, serta bagian serta kesatuan secara keseluruhannya, berdasarkan konsep-konsep di atas tersebut dan dengan ditambahkan hasil dokumentasi 2 lukisan (terdahulu dengan sekarang), yang kemudian 
kedua nya saling dihubungan dengan etik- emik maka dihasilkan matrik karakteristik seni lukis Sokaraja sebagai berikut.

Tabel 1. Matrik Karakteristik Seni Lukis Sokaraja

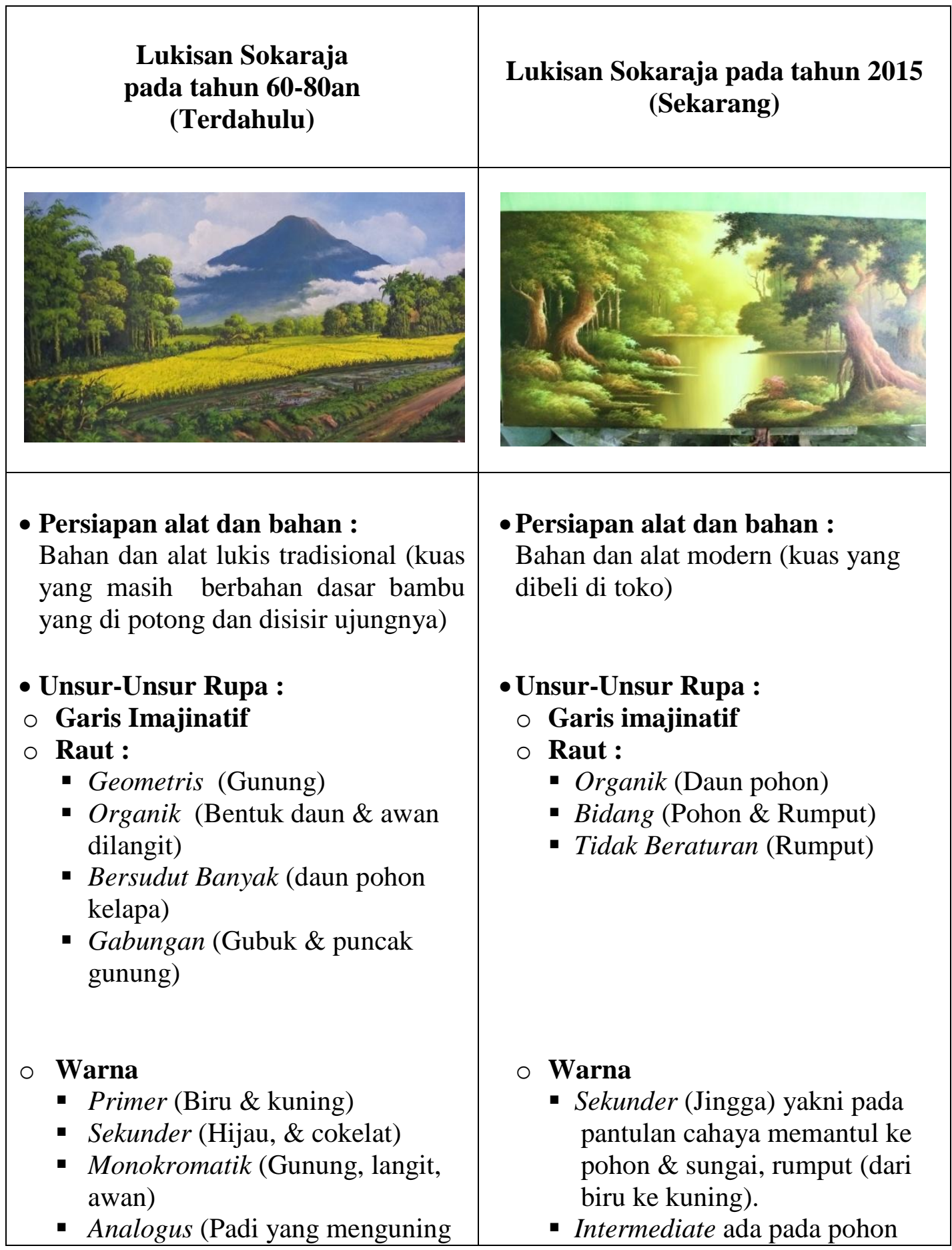




\begin{tabular}{|c|c|}
\hline $\begin{array}{l}\text { Tekstur (Hias \& spontan) } \\
\text { Gelap terang } \\
\text { - Adanya kedalaman ruang (jalan } \\
\text { \& pohon) } \\
\text { Ruang } \\
\text { - Perbedaan jarak, benda, warna, } \\
\text { obyek perspektif, ukuran awan } \\
\text { yang berbeda } \\
\text { - Prinsip Desain } \\
\text { O Komposisi } \\
\text { - Kesatuan \& Keserasian semua } \\
\text { obyek } \\
\text { - Irama (Sawah, rumput, batu) } \\
\text { - Dominasi (gunung) } \\
\text { - Keseimbangan asimetris (kanan } \\
\text { - } \text { kiri seimbang) } \\
\text { - Proporsi (semua obyek serasi) }\end{array}$ & $\begin{array}{l}\text { - Prinsip Desain } \\
\text { Komposisi } \\
\text { - Perbedaan jarak, benda, warna, } \\
\text { obyek perspektif, ukuran awan } \\
\text { yang berbeda } \\
\text { - Kesatuan \& Keserasian semua } \\
\text { obyek } \\
\text { - Irama (Rumput \& daun) } \\
\text { - Dominasi (Sinar Matahari) } \\
\text { - Keseimbangan asimetris (kanan } \\
\text { kiri seimbang) } \\
\text { - Proporsi (semua obyek serasi) } \\
\text { - Aliran lukisan } \\
\text { - Naturalisme dan realisme } \\
\text { - Keberagaman Tema } \\
\text { Konsep pemandangan alam fisik } \\
\text { khas daerah lain (beragam) } \\
\text { - sebagai perwujudan daerah } \\
\text { Sokaraja namun terinspirasi dari } \\
\text { - Sunda (sungai, waduk, air terjun) } \\
\text { - Dampak proses belajar di Sunda } \\
\text { Alasan permintaan } \\
\text { pasar/konsumen. }\end{array}$ \\
\hline
\end{tabular}




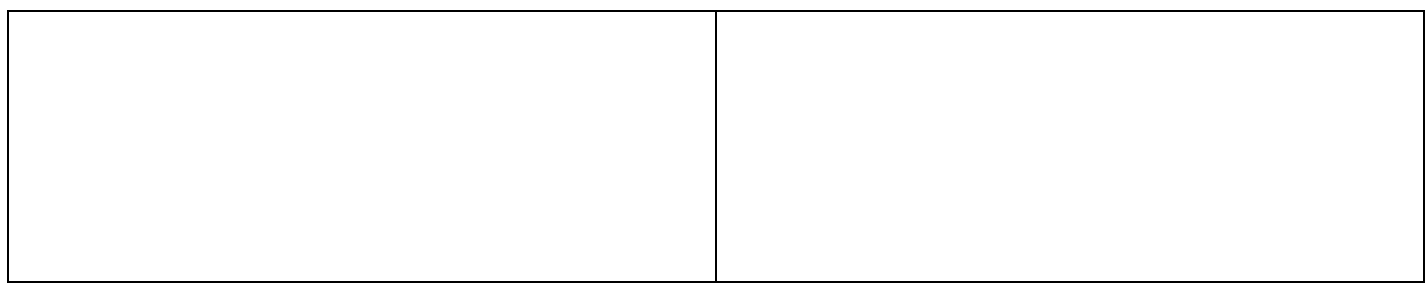

Setelah mengetahui karakteristik seni lukis Sokaraja, untuk menjawab masalah penelitian ini yakni permasalahan proses pewarisan lukisan Sokaraja, peneliti secara pokok menggunakan disiplin ilmu seni rupa dan antropologi budaya konsep kebudayaan secara pokok menggunakan konsep dari Budhisantoso (1953), Kroeber \& Kcluchkohn (2005), dan oleh Koentjaraningrat (1990).

Dalam pembahasan itu, apabila hanya menggunakan konsep yang diuraikan di atas dianggap belum dapat menjawab permasalahan secara tuntas, oleh karena itu dalam penelitian ini, dalam pembahasannya juga dilengkapi dengan berbagai konsep dari literarur yang lain. Perihal hasil penelitian dan pembahasan itu. Pemaparannya, tidak akan dipisah. Hal ini dikarenakan, setiap pembahasan hasil dari penelitian ini, dijelaskan menggunakan dasar pemikiran etik dan emik, yang hasilnya hanya akan didapat dan dipahami dari gabungan berbagai unsur yang dibahas tadi.

Selaras dengan konsep yang disampaikan oleh Budhisantoso (dalam Jurnal Seni Wiled, 1953:4) yakni di bab II pada landasan teori yang membahas bahwa kebudayaan merupakan keseluruhan cara hidup yang dianut oleh sekelompok sosial, kebiasaan yang diperoleh dengan cara belajar, cara berfikir, berperasaan dan berkepercayaan, abstraksi dari tingkah laku sosial, seperangkat pedoman untuk memecahkan masalah, mekanisme kontrol untuk mengatur tingkah laku secara normatif, ataupun seperangkat cara untuk menyesuaikan diri dengan lingkungan dalam arti luas maupun dengan sesama manusia.

Berdasarkan hasil observasi dan wawancara mengenai kondisi lapangan di Sokaraja, Hal tersebut diperjelas dengan apa yang disampaikan pelukis Sokaraja Bapak Sugeng, sebagai berikut :

“...Lukisan Sokaraja kuwe diturunna kawit jaman bien banget, kang wong tua sing ngajari ming anake, kang dulur ngajari meng dulur liyane, kang kanca ngajari kanca liyane, bar di ajari trus kon praktek dewek bar kuwe lukisane nembe bisa di dol, payu apa ora ne kuwe tergantung karo pasaran, lukisane payu dan pelukis bakal entuk duwit, pola kayak kuwe terus-terusan sampe bisa dienggo pendapatan sedina-dinane nang keluarga..."

(“...Lukisan Sokaraja itu diturunkan dari jaman dulu sekali, dari orang tua mengajarkan kepada anaknya, sodara mengajarkan ke sodara lain, teman mengajarkan ke teman 
lainnya, setelah diajari kemudian menyuruh untuk dipraktikan sendiri dan setelah itu lukisan baru bisa dijual, laku tidaknya lukisan tergantung dari pasaran, lukisan laku dan pelukis akan mendapatkan uang, jual beli tersebut yang terus menerus sampai bisa di gunakan sebagai pendapatan sehari-hari keluarga pelukis...")

Berdasarkan hasil wawancara tersebut, sehingga dapat diinterpretasikan, berdasarkan hasil wawancara dan observasi berupa foto pelukis sebagai bukti adanya interaksi antar masyarakat Sokaraja hingga menghasilkan pelukis-pelukis Sokaraja. Hal tersebut menunjukkan bahwa kegiatan melukis di Sokaraja dilakukan dari berawal sebuah proses yang diturunkan oleh sekelompok masyarakat Sokaraja kepada masyarakat Sokaraja lainnya, yang kemudian saling bersosialisasi sehingga menjadi sebuah tingkah laku masyarakat yang dilakukan terus-menerus, saling menyesuaikan dengan lingkungan antar sesama manusia hingga akhirnya menjadi kebiasaan dan menghasilkan pendapatan yang secara tidak langsung menyelesaikan permasalahan pada masyarakat Sokaraja, kebiasaan tersebut menghasilkan sebuah lukisan yakni lukisan Sokaraja, yang tentu setelah dijual akan menghasilkan uang sehingga menjadi mata pencaharian sebagian masyarakat Sokaraja yang berprofesi sebagai pelukis guna pemenuhan kebutuhan hidup.

Rangkaian di atas berkait pula dengan pendapat Kroeber dan Kcluchkohn (dalam mudji dan Hendar, 2005: 8-9) bahwa menurut Kroeber dan Kcluchkohn ada beberapa pemahaman pokok mengenai budaya yaitu pertama, dari sisi deskriptif yang cenderung melihat budaya sebagai totalitas yang menyusun keseluruhan hidup sosial sekaligus menunjukan sejumlah ranah yang berbentuk budaya. Kedua, sisi historis yang cenderung melihat budaya sebagai warisan yang dialih-diturunkan dari generasi satu ke generasi berikutnya. Ketiga, sisi psikologis yang cenderung memberi tekanan pada peran budaya sebagai pemecahan masalah yang membuat orang bisa berkomunikasi, belajar, atau memenuhi kebutuhan material maupun emosional. Keempat, sisi genetis yang melihat sisi asal usul bagaimana budaya itu bisa eksis atau tetap bertahan. Melihat budaya lahir dari interaksi antar manusia dan tetap bisa bertahan karena ditransmisikan dari satu generasi ke generasi berikutnya.

Ditemukan data kondisi masyarakat Sokaraja berdasarkan hasil wawancara menunjukan bahwa memang benar adanya warisan yang dialihkan dari pelukis terdahulu kepada pelukis sekarang, seperti yang di sampaikan Bapak Abdul Basir, yang berumur 88 tahun (salah satu pelukis Sokaraja yang masih hidup) diuraikan dalam petikan percakapan berikut ini :

“...pelukis Sokaraja generasi pertama kados Gesang, Ismail. Iha pak Ismail niku pak lek e kulo, nah kulo niku keponakane, pas kuwe pak Ismali ngendika 'Basir wis ora usah 
nerusna sekolah duwur-duwur, sekolah duwur-duwur tapi ra dadi nggo ngapa, mending sinau nglukis bae, nek kowe ana bakate mengko li teyeng' zaman niku pas Hindia Belanda (pas zaman jajahan Belanda). Lha njur kulo diwarahi teng Pak Ismail, lha kulo diwarahi sedela wis langsung nyantel pinter, sinau 3 tahun terus teyeng..."

(“...pelukis Sokaraja generasi pertama seperti Gesang, Ismail, dll. Lha Pak Ismail itu Paman saya, pada saat itu Pak Ismail bilang 'Basir sudahlah tidak usah sekolah buat apa, belajar melukis saja, kalau memang kamu berbakat pasti bisa. Jaman itu Jaman Hindia Belanda (penjajahan Hindia Belanda). Kemudian saya diajari melukis oleh Pak Ismali, saya diajari dengan waktu sebentar sudah langsung bisa, belajar 3 tahun sudah dapat melukis...”)

Setelah melihat hasil data lapangan di atas, dapat dipadupadankan dengan konsep yang diuraikan sebelumnya, bahwa lukisan Sokaraja masuk dalam sisi kedua yakni historisnya, lukisan Sokaraja terbukti memiliki sisi historis yang pasti yakni sisi penurunan dari generasi satu ke generasi lain, sisi psikologis dengan memecahkan permasalahan yang ada seperti yang disampaikan konsep pertama di atas oleh Budhisantoso, yang jelas memiliki sisi genetis, dari pelukis yang masih memiliki hubungan persaudaraan dengan pelukis lain (walaupun tidak semua pelukis).

Di dalam teori tindakan yang disampaikan oleh Koentjaraningrat (1990: 220) terkandung konsepsi bahwa dalam hal menganalisis suatu kebudayaan dalam keseluruhan perlu dibedakan secara tajam antara adanya empat komponen, yaitu diantaranya : (1) Sistem budaya atau cultural system, dengan demikian sistem budaya berfungsi sebagai adat istiadat, diantara adat istiadat seperti sistem normanya, yang secara lebih khusus lagi dapat dirinci ke dalam berbagai macam-macam norma menurut pranata-pranata yang ada dalam masyarakat bersangkutan. Fungsi inti dari sistem budaya adalah menata dan memantapkan tindakan-tindakan serta tingkah laku manusia. (2) Sistem sosial atau social system, terdiri dari aktivitas manusia dan tindakan-tindakan dan tingkah laku berinteraksi antar individu dalam rangka kehidupan masyarakat, sebagai rangkaian tindakan berpola yang berkaitan satu dengan yang lain, sistem sosial itu bersifat lebih konkret dan nyata dari pada sistem budaya, dalam arti bahwa tindakan manusia dapat dilihat dan diobservasi. (3) Sistem kepribadian atau personality system, mengenalkan soal isi jiwa dan watak individu yang berinteraksi sebagai warga masyarakat. (4) Sistem organisme atau organic system, melengkapi seluruh kerangka dengan mengikut-sertakan ke dalam proses biologick serta bio-kimia dalam organisme manusia.

Berdasarkan paparan mengenai teori tindakan oleh Koentjaraningrat, maka dibuat kerangka untuk mempermudah pemahaman dalam penggunaan teori tersebut, bagan tersebut berawal dari masyarakat yang memiliki kebudayaan dan terdiri dari empat 
komponen yang kemudian menghasilkan wujud yang berbeda-beda, dan menghasilkan sebuah fungsi yang melalui proses sehingga hasil akhir mencapai sebuah pembudayaan. Bagan di bawah telah disusun oleh kelompok studi Harvard dibawah pimpinan Talcott Person, yang akan di uraikan sebagai berikut.

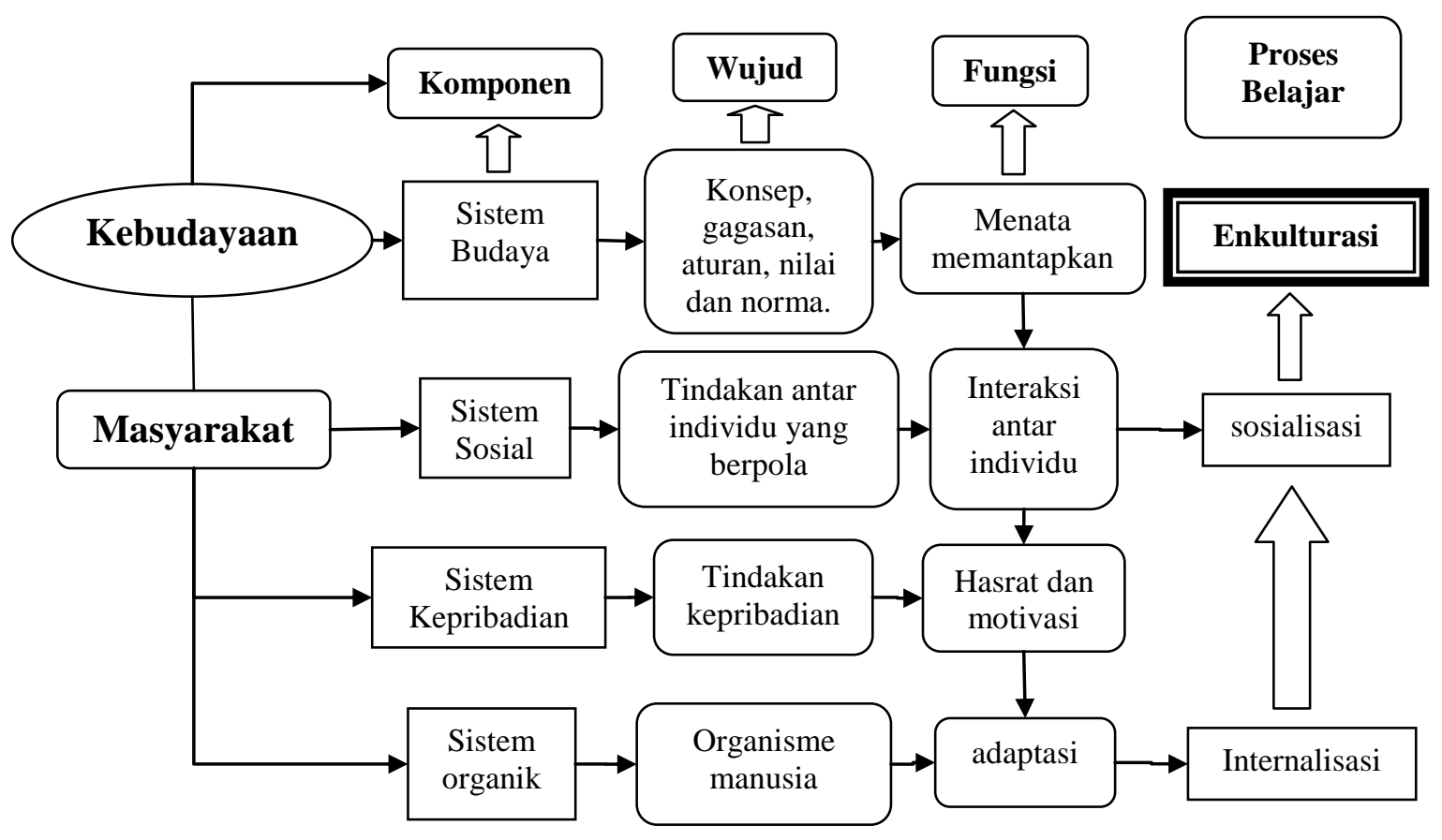

Gambar 8. Bagan Teori Tindakan dalam Kebudayaan

(Talcott Parsons dalam Koentjaraningrat, 1990: 223)

Berdasarkan pijakan teori milik Koentjaraningrat di atas, yang berbicara empat komponen yakni mengenai ; Sistem budaya, Sistem sosial, Sistem kepribadian, Sistem organisme. Kemudian dihubungkan dengan hasil petikan wawancara dengan salah satu pelukis Sokaraja, maka jelas bahwa sistem budaya atau cultural system, dengan demikian sistem budaya berfungsi sebagai adat istiadat, diantara adat istiadat seperti sistem normanya, yang secara lebih khusus lagi dapat diperinci ke dalam berbagai macam-macam norma menurut pranata-pranata yang ada dalam masyarakat bersangkutan. Fungsi inti dari sistem budaya adalah menata dan memantapkan tindakan-tindakan serta tingkah laku manusia. Sistem budaya di masyarakat Sokaraja tidak yang terlalu religius tapi juga tidak pula yang mendukung hal-hal diluar batas norma hal tersebut terlihat dari jenis lukisan yang ada di Sokaraja sopan, dan bertema pemandangan dan asli fisik pemandangan alam Sokaraja. Kedua, sistem sosial atau social system, terdiri dari aktivitas manusia dan 
tindakan-tindakan dan tingkah laku berinteraksi antar individu dalam rangka kehidupan masyarakat, sebagai rangkaian tindakan berpola yang berkaitan satu dengan yang lain, sistem sosial itu bersifat lebih konkret dan nyata dari pada sistem budaya, dalam arti bahwa tindakan manusia dapat dilihat dan diobservasi.

Hal tersebut jelas sesuai karena adanya aktifitas-aktifitas dalam proses pembuatannya suatu karya seni. Ketiga, sistem kepribadian atau personality system, mengenalkan soal isi jiwa dan watak individu yang berinteraksi sebagai warga masyarakat, proses kegiatan melukis di Sokaraja tidak akan berjalan bila watak asli tiap individu di masyarakat tidak mau menerima, karena sebaliknya maka akhirnya muncul hasrat dan motivasi untuk melakukan kegiatan melukis. Keempat, sistem organisme atau organic system, melengkapi seluruh kerangka dengan mengikut-sertakan ke dalam proses biologick, ketiga hal tersebut tidak akan terjadi bila tidak di gerakan oleh sistem jaringan tubuh, dalam hal ini kegiatan melukis digerakan oleh seluruh indra di tubuh. Keempat konsep tersebut kemudian saling bersinergi untuk kemudian masuk dalam masyarakat dan disosialisasikan kepada masyarakat yang lebih luas sehingga mencapai sebuah pembudayaan, kegiatan yang dilakukan terus menerus.

Guna mendukung konsep teori dan pembahasan di atas milik Koentjaraningrat tersebut, yakni mengenai sistem budaya, Sistem sosial, Sistem kepribadian, Sistem organisme, maka ditambahkan lagi sebuah konsep baru yakni milik Ahimsa Putra, (2012: 6) mengenai nilai -nilai atau values, yakni patokan yang digunakan sesuatu itu baik atau buruk, benar atau salah, bermanfaat atau tidak. Berkenaan dengan hal tersebut maka nilai ilmu sosial budaya yang baik adalah yang dapat membuat masyarakat dan budayanya lebih baik keadaannya dari waktu ke waktu, memperluas wawasan kemanusiaan warga masyarakat pada umumnya. Sistem nilai yang baik dapat membuat warga masyarakatnya memahami dan menghargai kebudayaan. Berdasarkan konsep baru milik Ahimsa Putra tersebut dapat diperoleh bahwa sistem budaya, Sistem sosial, Sistem kepribadian, Sistem organisme itu memiliki nilai dalam setiap aspeknya, tentunya nilai yang diharapkan adalah nilai yang baik.

Konsep mengenai komunikasi di atas diperkuat kembali oleh pendapat Koentjaraningrat, (2009: 184-190), yang menyatakan pada dinamika dan kebudayaan masyarakat adanya proses belajar kebudayaan sendiri, dengan mengalami proses internalisasi, sosialisasi, dan yang terakhir proses enkulturasi, yang diuraikan bahwa proses internalisasi merupakan proses panjang sejak seorang individu belajar menanamkan dalam kepribadiannya segala perasaan, hasrat, nafsu, dan emosi yang diperlukan sepanjang 
hidupnya. Sedangkan proses sosialisasi berkaitan dengan proses belajar kebudayaan dalam hubungan dengan sistem sosial, dalam proses itu seorang individu dari masa anak hingga masa tuanya belajar pola-pola tindakan dalam interaksi dengan segala macam individu sekelilingnya yang menduduki beraneka macam peranan sosial yang mungkin ada dalam kehidupan sehari-hari. Hingga mencapai sebuah enkulturasi, yakni proses seorang individu mempelajari dan menyesuaikan alam pikiran serta sikapnya dengan adat, sistem norma dan peraturan yang hidup dalam kebudayaannya.

Berdasarkan hasil observasi dan wawancara mengenai kondisi lapangan di Sokaraja, Hal tersebut diperjelas dengan apa yang disampaikan pelukis Sokaraja Bapak Sugeng, sebagai berikut :

“...Lukisan Sokaraja kuwe diturunna kawit jaman bien banget, kang wong tua sing ngajari ming anake, kang dulur ngajari meng dulur liyane, kang kanca ngajari kanca liyane, bar di ajari trus kon praktek dewek bar kuwe lukisane nembe bisa di dol, payu apa ora ne kuwe tergantung karo pasaran, lukisane payu dan pelukis bakal entuk duwit, pola kayak kuwe terus-terusan sampe bisa dienggo pendapatan sedina-dinane nang keluarga..."

(“...Lukisan Sokaraja itu diturunkan dari jaman dulu sekali, dari orang tua mengajarkan kepada anaknya, sodara mengajarkan ke sodara lain, teman mengajarkan ke teman lainnya, setelah diajari kemudian menyuruh untuk dipraktikan sendiri dan setelah itu lukisan baru bisa dijual, laku tidaknya lukisan tergantung dari pasaran, lukisan laku dan pelukis akan mendapatkan uang, jual beli tersebut yang terus menerus sampai bisa di gunakan sebagai pendapatan sehari-hari keluarga pelukis...")

Berdasarkan hasil wawancara tersebut, sehingga dapat diinterpretasikan, berdasarkan hasil wawancara dan observasi berupa foto pelukis sebagai bukti adanya interaksi antar masyarakat Sokaraja hingga menghasilkan pelukis-pelukis Sokaraja. Hal tersebut menunjukkan bahwa kegiatan melukis di Sokaraja dilakukan dari berawal sebuah proses yang diturunkan oleh sekelompok masyarakat Sokaraja kepada masyarakat Sokaraja lainnya, yang kemudian saling bersosialisasi sehingga menjadi sebuah tingkah laku masyarakat yang dilakukan terus-menerus, saling menyesuaikan dengan lingkungan antar sesama manusia hingga akhirnya menjadi kebiasaan dan menghasilkan pendapatan yang secara tidak langsung menyelesaikan permasalahan pada masyarakat Sokaraja, kebiasaan tersebut menghasilkan sebuah lukisan yakni lukisan Sokaraja, yang tentu setelah dijual akan menghasilkan uang sehingga menjadi mata pencaharian sebagian masyarakat Sokaraja yang berprofesi sebagai pelukis guna pemenuhan kebutuhan hidup.

Ditemukannya kegiatan proses belajar di sanggar dan di rumah. Untuk di sanggar setting: tempat dilakukan di sanggar, pelakun(masyarakat Sokaraja bersaudara baik yang 
ataupun tidak), dilakukan bersama-sama. Aktif dan pasif, aktif terjadi dulu tahun 196080an, pasif pada waktu sekarang. Apa yang diwariskan, keahlian melukis/cara melukis. Untuk proses belajar di rumah, setting tempat dilakukan di rumah/keluarga, pelaku (anggota keluarga saja) dilakukan sebatas anggota keluarga (sendiri), kegiatan masih aktif hingga sekarang (2015), apa yang diwariskan keahlian berupa keahlian melukis/cara melukis.

Berdasarkan berbagai macam ulasan konsep-konsep di atas yang dipadukan dengan seluruh data-data penelitian di Sokaraja, kemudian diselaraskan dan diinterpretasikan menjadi sebuah simpulan, guna mendukung simpulan-simpulan di atas maka ditambahakan juga konsep mengenai komunikasi, karena semua hal tidak akan terjalin baik bila tidak ada komunikasi yang baik pula. Seperti yang disampaikan oleh (Effendy, 1990 : 13) pentingnya bahasa dalam sebuah komunikasi, yakni bagaimana proses berlangsungnya proses komunikasi yang terdiri dari atas proses rohaniah komunikan dengan bahasa sebagai media atau penghubung dan komunikasi berlangsung apabila terjadi kesamaan makna dalam pesan yang diterima oleh komunikan, dengan arti lain komunikasi adalah proses membuat sebuah pesan setala (tuned) bagi komunikator dan komunikan.

Berbicara komunikasi maka semua hal tersebut perlu adanya budaya sebagai suatu informasi dan komunikasi, seperti yang disampaikan Kluckhohn dan Kelly, 1945 (dalam Liliweri, 2014: 23-24) yang menyatakan kebudayaan juga dapat dipandang sebagai informasi dan Hall, 1959, 1976 (dalam Liliweri, 2014: 23-24) yang menyatakan sistem komunikasi. Kedua pendangan tersebut menghasilkan sebuah konsep baru bahwa kebudayaan merupakan matriks yang kompleks dari unsur-unsur sosial yang berbentuk abstrak dan akhirnya melekat pada jiwa individu maupun kelompok, akibatnya kebudayaan terbentuk menjadi pola hidup meletakkan orientasi dunia, dan kebudayaan memungkinkan orang untuk memahami lingkungan, melakukan transisi dari rahim dari kehidupan yang tidak kelihatan menjadi nampak.

Mengangkat soal pewarisan maka akan berbicara cara belajar dan pendidikan, karena lukisan Sokaraja terbentuk berdasarkan cara belajar dan di ketahui bahwa lukisan Sokaraja berada pada pendidikan nonformal dan informal, sehingga di bawah ini dicantumkan pula matrik bentuk pewarisan dari seni lukis Sokaraja, sebagai berikut: 
Tabel 2. Matrik Bentuk Pewarisan Seni Lukis Sokaraja

\begin{tabular}{|c|c|}
\hline Pendidikan Nonformal & Pendidikan Informal \\
\hline $\begin{array}{l}\text { - Setting : } \\
\text { O Tempat dilakukan di sanggar. } \\
\text { ○ Pelaku (masyarakat Sokaraja } \\
\text { bersaudara baik yang ataupun tidak) } \\
\text { ○ Dilakukan bersama-sama } \\
\text { - Aktif dan pasif : } \\
\text { O Aktif dulu tahun 1960-80an } \\
\text { - Pasif pada waktu sekarang. } \\
\text { - Apa yang diwariskan } \\
\text { O Keahlian melukis/cara melukis }\end{array}$ & $\begin{array}{l}\text { - Setting : } \\
\circ \text { Tempat dilakukan di } \\
\text { rumah/keluarga. } \\
\circ \text { Pelaku (Anggota keluarga saja) } \\
\circ \text { Dilakukan sebatas anggota } \\
\text { keluarga (sendiri). } \\
\text { - Aktif dan pasif : } \\
\text { O Aktif hingga sekarang (2015) } \\
\text { - Apa yang diwariskan } \\
\text { O Keahlian melukis/cara melukis }\end{array}$ \\
\hline
\end{tabular}

Pada bagaian ini disampaikan hasil penelitian dan pembahasan untuk menjelaskan masalah penelitian yakni permasalahan pemasaran seni lukis lukisan Sokaraja dalam konteks pasar seni, maka dalam mengkajinya peneliti menggunakan konsep mengenai pasar. Sebagian besar konsep pasar diambil pemikiran dari Swasta \& Sukotjo (2002) dan Kotler Amstrong (2008).

Kaitan produk dengan penentuan harga, maka lukisan Sokaraja adalah suatu barang yang dijual, menurut Kotler dan Armstrong (2008: 2) dalam perekonomian sekarang ini, tentu pertukaran barang tidak lagi dilakukan secara barter, tetapi dilakukan dengan menggunakan alat pembayaran atau alat penukar yang disebut uang. Dalam ilmu ekonomi, uang dikatakan sebagai sejumlah nilai pertukaran. Penjual akan menerima sejumlah uang sebagai imbalan dari usahanya menjual barang kepada pembeli. Sebaliknya, pembeli akan membayarkan sejumlah uang kepada penjual sebesar nilai barang yang dibelinya. 
Setelah melakukan observasi di lapangan yakni di Sokaraja, diperoleh data berupa foto dokumentasi langsung ketika berada di galeri milik Bapak Syarif, galeri tersebut berada di sepanjang jalan di Sokaraja, foto untuk lebih jelasnya adalah sebagai berikut.

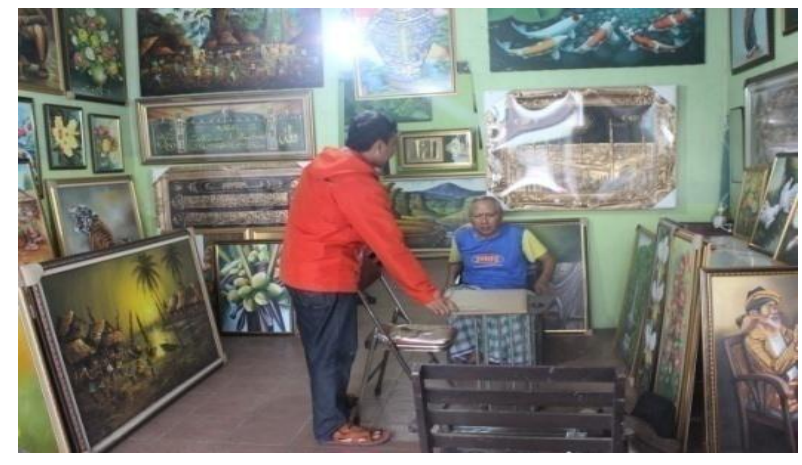

Gambar 9. Foto Lukisan Sokaraja dan pembelinya

Proses Transaksi Pembelian Lukisan Di Galeri Lukisan Milik

Bapak Syarif (Dokumentasi Setyaningrum, 2015)

Berdasarkan gambar di atas terlihat Bapak Syarif, sedang melakukan aktifitas membungkus sebuah lukisan yang sudah ditawar dan akan dibeli oleh Dimas, kemudian terlihat jelas bahwa Dimas konsumen lukisan Sokaraja, hendak akan membayar lukisan Sokaraja tersebut, sistem pembayarannya pun dengan membeli berupa uang.

Tanggapan yang positif dari masyarakat yang sekarang yang dituju, biasa dikenal dengan sebutan pasar atau market. Marketing dan market dalam dunia ekonomi tidak dapat dipisahkan karena adanya marketing atau pemasaran yang pasti karena adanya market atau pasar yang dituju (Swastha dan Sukotjo, 2002: 191-192).

Di bawah ini merupakan hasil observasi dokumentasi berupa foto yang diabadikan, terlihat jelas adanya konsumen yang bernama Dimas, asli Sokaraja dan berumur 20 tahun yang sedang memilah-milih lukisan Sokaraja dan menawarnya untuk kemudian akan dibeli untuk konsumsi pribadi di rumahnya, foto untuk lebih jelasnya dapat dilihat di bawah sebagai berikut :

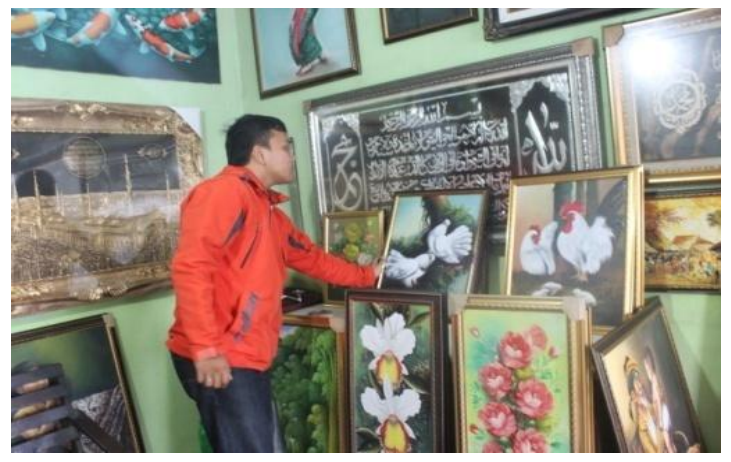

Gambar 10. Dimas seorang konsumen lukisan sedang melihat-lihat Lukisan Sokaraja Di Galeri (Dokumentasi Setyaningrum, 2015) 
Kemudian, di tambahkan kembali oleh Haryono (2008: 129) mengenai adanya art for art dan art for mart, dalam kaitan dengan pendapat tersebut maka yang dimaksud lukisan Sokaraja diciptakan dalam rangka untuk kepentingan industri atau dijual.

Dalam rangka menyikapi pijakan konsep milik Haryono di atas, maka di bawah ini di cantumkan foto hasil observasi sebagai berikut :
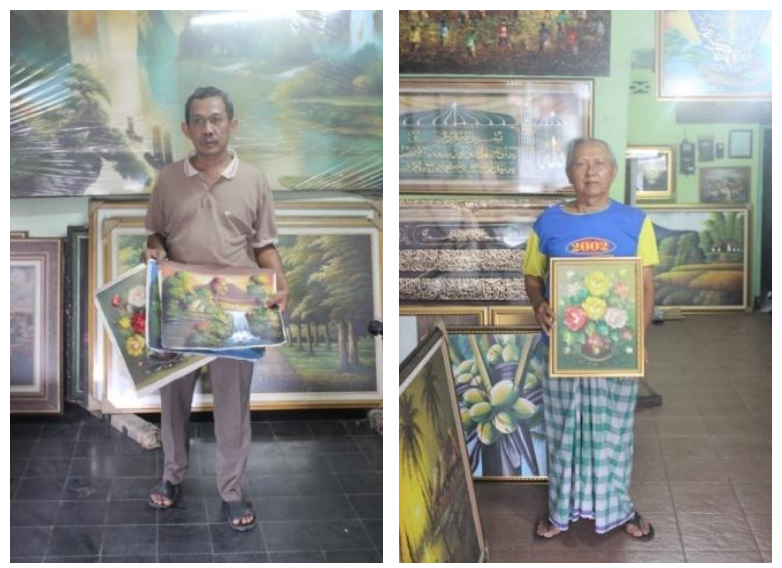

\section{Gambar 11. Pelukis Bapak Sugeng dan Syarif sedang Menunjukkan Lukisan Sokaraja di Galeri (Dokumentasi Setyaningrum, 2015)}

Gambar di atas memperjelas bahwa lukisan Sokaraja dijual di dua galeri di sepanjang jalan Sokaraja. Kemudian, ditambahkan lagi hasil petikan wawancara yang di sampaikan pelukis Bapak Sugeng, sebagai berikut :

“...Aku nglukis genah anu ana jalukan kang konsumen, aku juga ra bakal nglukis nek pancen ora ana sing tuku. Nglukise be ora ana makna apa, kur nglukis pemandangan bae, ora ana maksut misal nglukis wit witan maksute ben kepriwe, ora. Ya kur ben apik bae, pemandangan ya pancen ana wit witane..."

(“...Saya melukis hanya karena ada permintaan dari konsumen, saya juga tidak akan melukis kalau memang tidak ada yang membelinya. Melukisnya pun tidak ada makna lebih. Hanya melukis pemandangan saja, tidak ada maksut lain misalnya saja saya melukis pepohonan supaya memiliki kesan apa, tidak. Ya hanya biar bagus, pemandangan kan memang ada pepohonannya...”)

Berdasarkan pijakan konsep di atas dan hasil petikan wawancara di atas maka dapat diinterpretasikan sebagai berikut :

Lukisan Sokaraja merupakan lukisan yang di dalam nya tidak ada halnya estetika khusus, hal tersebut sesuai seperti yang disampaikan pelukis Sokaraja bahwa melukis hanya karena ada permintaan pasar tanpa terlalu mempedulikan estetikanya, hal tersebut berati jelas sekali lukisan Sokaraja merupakan art for mart, bukan merupakan art for art dalam 
kaitan dengan pendapat tersebut, maka yang dimaksud lukisan Sokaraja diciptakan dalam rangka untuk kepentingan industri atau dijual. Oleh karena tujuan penciptaannya untuk dijual, maka sudah barang tentu materi produknya juga menyesuaikan dengan selera pasar.

Secara utama Marketing Mix menurut Swastha dan Sokotjo (2002: 193) adalah kombinasi dari empat kegiatan yang merupakan inti dari sistem pemasaran perusahaan, yakni tentang produk, harga, promosi, dan sistem distribusi. Di sinilah peran marketing sangat penting dalam upaya sebuah produk sampai ke masyarakat pembeli. Sehingga berdasarkan konsep milik Sukotjo, marketing mix pada galeri terdiri dari perencanaan produk, yang berupa persiapan mengambil produk lukisan dari pelukis, mengambil lukisan berdasarkan permintaan konsumen dan berdasarkan lukisan terlaris di galeri.

Penentuan harga lukisan berdasarkan harga yang ditentukan oleh pelukis, untuk kemudian menentukan harga sendiri. Pemilik galeri aktif melakukan promosi via internet atas bantuan Pemda dan melakukan promosi dengan memajang lukisan di galeri keluarga. Galeri mendistribusikan dengan cara menjual kepada konsumen pembeli di Sokaraja \& diluar Sokaraja serta penjual lain yang akan menjual kembali lukisan tersebut. Guna memperjelas maka dibawah disajikan matrik pemasaran seni lukis Sokaraja.

Tabel 3. Matrik Pemasaran Produk Lukisan Sokaraja

\begin{tabular}{|c|c|c|c|}
\hline \multirow{2}{*}{$\begin{array}{l}\text { Marketing Mix } \\
\text { (Managemen } \\
\text { Pemasaran) }\end{array}$} & \multirow{2}{*}{ Pelukis Sokaraja } & \multicolumn{2}{|c|}{ Galeri Di Sokaraja } \\
\hline & & Galeri Hf & Galeri Keluarga \\
\hline $\begin{array}{c}\text { \# } \text { Perencanaan } \\
\text { (Produk) }\end{array}$ & $\begin{array}{l}\text { Persiapan alat \& } \\
\text { bahan, dan tema } \\
\text { lukisan } \\
\text { o Berdasarkan } \\
\text { permintaan } \\
\text { konsumen/pasar }\end{array}$ & $\begin{array}{l}\text { Persiapan } \\
\text { pengambilan } \\
\text { produk lukisan } \\
\text { baru dilakukan } \\
\text { dalam waktu } \\
\text { lama (stok baru } \\
\text { hampir tidak } \\
\text { ada) }\end{array}$ & $\begin{array}{l}\text { - Persiapan } \\
\text { mengambil produk } \\
\text { lukisan dari } \\
\text { pelukis. } \\
\text { o Berdasarkan } \\
\text { permintaan } \\
\quad \text { konsumen. } \\
\text { ○ Berdasarkan } \\
\text { lukisan terlaris } \\
\quad \text { di galeri } \\
\text { - Berdasarkan harga } \\
\text { yang ditentukan } \\
\text { oleh pelukis, untuk } \\
\text { kemudian } \\
\text { menentukan harga }\end{array}$ \\
\hline
\end{tabular}




\begin{tabular}{|c|c|c|c|}
\hline \# Promosi & $\begin{array}{l}\text { tidaknya) tidaknya } \\
\text { lukisan } \\
\text { - Waktu Lama } \\
\text { pembuatan. } \\
\text { - Pelukis melakukan } \\
\text { promosi pasif } \\
\text { (hanya dirumah }\end{array}$ & $\begin{array}{l}\text { menentukan } \\
\text { harga sendiri. } \\
\text { - Pemilik galeri } \\
\text { melakukan } \\
\text { promosi aktif. }\end{array}$ & $\begin{array}{l}\text { - Pemilik galeri aktif } \\
\text { melakukan : } \\
\text { o promosi via } \\
\text { internet atas } \\
\text { bantuan Pemda } \\
\text { dan melakukan } \\
\text { promosi dengan } \\
\text { memajang } \\
\text { lukisan di galeri } \\
\text { keluarga. }\end{array}$ \\
\hline \# Distribusi & $\begin{array}{l}\text { - Pelukis melakukan } \\
\text { distribusi : } \\
\text { ○ Ke galeri-galeri } \\
\text { yang ada di } \\
\quad \text { Sokaraja. } \\
\text { ○ } \\
\text { Melakukan } \\
\text { distribusi ke luar } \\
\text { daerah Sokaraja. } \\
\text { Ke penjual lain } \\
\\
\text { dengan tujuan } \\
\\
\text { untuk dijual } \\
\text { kembali. }\end{array}$ & $\begin{array}{l}\text { - Galeri } \\
\text { mendistribusika } \\
\mathrm{n} \\
\text { o menjual } \\
\text { kepada } \\
\text { konsumen } \\
\text { pembeli } \\
\text { lukisan } \\
\text { Sokaraja. }\end{array}$ & $\begin{array}{l}\text { - Galeri } \\
\text { mendistribusikan: } \\
\text { o menjual kepada } \\
\text { konsumen } \\
\text { pembeli di } \\
\text { Sokaraja \& } \\
\text { diluar Sokaraja } \\
\text { O Penjual lain } \\
\text { yang akan } \\
\text { menjual kembali } \\
\text { lukisan tersebut. }\end{array}$ \\
\hline
\end{tabular}

\section{KESIMPULAN DAN SARAN}

Pada karakteristik seni lukis Sokaraja, terjadi dua perbedaan seni lukis Sokaraja yang mencolok antara tahun terdahulu berkisar tahun (60-80an) dengan sekarang tahun (2015) terlihat dari analisis berbagai macam unsur kesenirupaan dan prinsip desain, aliran seni lukis dan keseragaman tema.

Pada proses pewarisan seni lukis di Sokaraja, adanya proses belajar berupa perilaku melukis berdasarkan rangkaian sistem budaya, sosial, kepribadian dan organik untuk kemudian diinternalisasi, disosialisasikan hingga mencapai enkulturasi. Proses belajar tersebut ditemukan pada kategori pendidikan nonformal di sanggar, dan pendidikan informal masyarakat dan keluarga di Sokaraja.

Pada permasalahan pemasaran dianalisis berdasarkan marketing mix yang terdiri dari perencanaan produk, berupa persiapan alat \& bahan, berdasarkan tema lukisan, permintaan konsumen/pasar dan bahan yang digunakan. Penentuan harga berdasarkan ukuran (besar 
kecilnya) lukisan, kesulitan (rumit tidaknya) tidaknya lukisan, waktu lama pembuatan. Promosi, pelukis melakukan promosi pasif (hanya dirumah). Pelukis melakukan distribusi ke galeri-galeri yang ada di Sokaraja. melakukan distribusi ke luar daerah Sokaraja ke penjual lain dengan tujuan untuk dijual kembali.

Marketing mix pada galeri terdiri dari perencanaan produk, yang berupa persiapan mengambil produk lukisan dari pelukis, mengambil lukisan berdasarkan permintaan konsumen dan berdasarkan lukisan terlaris di galeri. Penentuan harga lukisan berdasarkan harga yang ditentukan oleh pelukis, untuk kemudian menentukan harga sendiri. Pemilik galeri aktif melakukan promosi via internet atas bantuan Pemda dan melakukan promosi dengan memajang lukisan di galeri keluarga.Galeri mendistribusikan dengan cara menjual kepada konsumen pembeli di Sokaraja \& diluar Sokaraja serta penjual lain yang akan menjual kembali lukisan tersebut.

Kegiatan untuk membuat produk lukisan Sokaraja yang seyogyanya dipertahankan di masyarakat Sokaraja. Seiring kemajuan teknologi dan perkembangan jaman sudah seharusnya menjadi salah satu alat kesejahteraan di lingkungan masyarakat Sokaraja dan mengurangi angka pengangguran. Namun, keberadaan produk lukis Sokaraja yang sudah membudaya pada masyarakat justru semakin berbalik arah. Hal tersebut mendorong perlu adanya kerjasama yang baik antara pihak pelukis/pelaku seni, pemerintah, galeri lukisan, konsumen pembeli maupun pihak-pihak lain baik dilingkungan masyarakat ataupun diluar masyarakat pelaku seni di Sokaraja.

\section{DAFTAR PUSTAKA}

Alfauzani, I. 2008. "Karya Seni Grafis Hardboardcut: Kehidupan Pasar Tradisional". Proyek Studi. Jurusan Seni Rupa Fakultas Bahasa dan Seni Universitas Negeri Semarang.

Budhisantoso. 1994. "Kesenian dan Kebudayaan”. Jurnal Seni Wiled. Hlm 4-5. Surakarta: STSI.

Effendi, O U. 1990. Ilmu komunikasi Teori dan Praktek. Bandung:PT Remaja Rosdakarya Haryono, T. 2008. Seni Pertunjukan dan Seni Rupa dalam Perspektif Arkeologi Seni. Solo: ISI Press.

Mudji, S \& Hendar P. 2005. Teori-Teori kebudayaan. Bandung: Kanisius.

Koentjaraningrat. 1990. Pengantar Ilmu Antropologi. Jakarta: PT Rineka cipta

Koentjaraningrat. 2009. Pengantar Ilmu Antropologi. Jakarta: PT Rineka Cipta

Kotler, P dan Armstrong. 2008. Prinsip-Prinsip Pemasaran. Editor Adi Maulana, Devri Barnardi, Wibi Hardani. Edisi 12. Jakarta: Erlangga.

Liliweri, A. 2014. Pengantar Studi Kebudayaan. Bandung: Nusa Media

Putra, A S H. 2012. Paradigma Ilmu Sosial-Budaya Sebuah Pandangan. Yogyakarta: UGM 
Rohidi, T R. 2011. Metodologi Penelitian Seni. Semarang: CV Cipta Prima Nusantara.

Rondhi, Moh. dan Anton Sumartono. 2002. “Tinjauan Seni Rupa I". Hand Out Jurusan Seni Rupa, FBS UNNES Semarang : Jurusan Seni Rupa FBS Universitas Negeri Semarang.

Sugiharto, B. 2013. Untuk Apa Seni. Bandung: Matahari.

Sunaryo, A. 2002. "Nirmana I". Hand Out Jurusan Seni Rupa, FBS UNNES Semarang : Jurusan Seni Rupa FBS Universitas Negeri Semarang.

Swastha, B dan Ibnu S. 2002. Bisnis Modern. Yogyakarta: Liberty 